\title{
HALAQAH TRADITION IN BUILDING RABBANI CHARACTERS IN PESANTREN AL-ISLAM LAMONGAN, EAST JAVA, INDONESIA
}

\author{
Muhammad Hambal \\ e-mail: abu.hana.tsania@gmail.com
}

\begin{abstract}
Abstrak: This research aims to reveal the basis of the halaqah practice in the Pesantren alIslam Lamongan, the implementation of the learning and formation of character through halaqah, and the way the system may build Islamic personality. The method used in this reseach was qualitative. The results of this research are as follows. Firstly, the halaqah practiced in the pesantren al-Islam was based on the ideas presented by the kyais and the management as formulized in the khiththah of the pesantren namely to have a rabbani generation with faith and sincerity, good morals, high spirituality, wide knowledge insights, healthy and strong physical condition, and readiness to make some propaganda about Islam. Secondly, the implementation of halaqah in Pesantren al-Islam may be classified into two categories. (1) halaqah taklim, intended to give some insights to the santries on the right aqidah and the correct worship. The employed techniques of the halaqah implementation were bandongan, sorogan or the combination of the two. (2) halaqah tarbiyah, intended to build santries to become muslims with noble morals and with some awareness and spirits of teaching and of struggling Islam. The technique of the halaqah implementation is to give materials of tazkiyat al-nafs accompanied with 'amaliah ibadah sunnah, and teaching and harakah materials and also guidance in reciting the Holy Qur'an and in guiding the characters.
\end{abstract}

Keywords: Halaqah, Character Building, Pesantren.

\section{A. Introduction}

Education, as asserted in Mulkan $^{1}$ is the most effective social engineering model to prepare a form of a future community. It is a significant element to live the life since along one's life journey, it is used as the barometer to reach values of his/her life. Of course, education is very important for each human being, because without it, it is impossible for a human community to develop in line with the ideal in making advancements, changes, prosperity, and happines as their way of life. The higher the human beings have ideals, the higher the demand for education for reaching them will be, as stated in the QS. AlMujadalah: 11.

Education in Islam not only give an emphasis on the mental and physical aspects as commonly happens in the

\footnotetext{
${ }^{1}$ Mulkan, Paradigma Intelektual Muslim. (Yogyakarta: Sipress, 2013), 21.
}

education in Western countries, but also touch upon moral and faith. Good moral should possess a guarrantor, and the best guarrntor is a strong faith. Therefore good graduates are those with good faith and good charity, charity which is based on the faith ${ }^{2}$.

Human beings are controlled by their ways of life. Since faith is a way of life, human beings are governed by their faith, and their essence is their mind. As a result, it is the mind which becomes the target of education and which should be filled with faith ${ }^{3}$.

Therefore, there are three expected characteristics possessed by any graduate, first, they have healthy and strong bodies, second, they are smart

\footnotetext{
${ }^{2}$ Ahmad Tafsir, Filsafat Pendidikan Islami. (Bandung: PT. Rosda, 2010), 100.

${ }^{3}$ Ahmad Tafsir, Ilmu Pendidikan Islami. (Bandung: PT. Rosda, 2012), 107.
} 
and intelligent and they have strong faith ${ }^{4}$.

This statement is in line with Abuddin Nata's that for moslem families, they should choose schools with excelence in the fields of science, technology, competence and experience, but also in those of personality and noble chracter ${ }^{5}$.

Abu Hasan Ali al-Nadawi also explains that schools should be concerned with aspects of Islamic education so that they are able to produce generations (graduates) with adequate science, healthy mind, strong physical condition and faith. Under guidance from their teachers, they possess high spirits in doing their religious lives, they are ready to make struggle and sacrification in sailing through their lives, they may grow with spirits in building sincere brotherhoods and pure loves, they ready to help and give prioritity to others' interest ${ }^{6}$.

Based on the descriptions above, Islamic education is the one oriented into five pillars of religion, namely faith, courtesy, morals, worship, and muamalat (social relationship). Two pillars, faith and worship deal with matters in hereafter, while the rest, courtesy, morals, and social relationship, with world affairs. If the five pillars are carefully paid attention in education, the education will produce human beings with strong faith, correct worship, good moralsand couresy, and with good ability in interacting with the community and in being invlved with the life in accordance with skills they posses.

${ }^{4}$ Ahmad Tafsir, Filsafat Pendidikan Islami. (Bandung: PT. Rosda, 2010), 80.

5 Abudin Nata, Kapita Selekta Pendidikan Islam. (Depok: PT. Rajawali Pres, 2013), 110.

${ }^{6}$ Al-Nadawi, Nahwa al-Tarbiyah al-Islamiyah al-Hurrah fi al-Hukumat wa al-Bilad alIslamiyah. (Beirut: Darul Irsyad, 1969). 23.
An institution that pays attention to the five pillars and that should not be neglected in the national education is Pondok Pesantren. Regarding the phenomenon of the moral desctruction at present, many experts start considering that the educational system of Pesantren may serve as one of the solutions to realice educational products who are not only smart, intelligent, and perceptive, but also are also noble hearted and good morals. It is understandable since Pesantrens possess some characteristics that may reach such a goal.

Consequently, since the last fifth years, the discourse on Pesantren has been showing a quick development. It may be seen from various focuses of discourses, studies and researches, especially after the contributions and the roles of Pesantrens have been admitted not only as a "sub-culture" (referring to an institution that has a unique typologi and that deviates from the common life pattern in this country) but also as a "cultural institution" (delienating an education that possesses certain characters and that also opens to an external hegemony) ${ }^{7}$.

According to Nasir ${ }^{8}$, kyai really determines the success of education in a pesantren, since he is an ideal figure in the community of santries. Charism a kyai possesses due to his closeness with Allah makes santries really respect him and try to model his attitudes and behavior.

Morevoer, the centralization of education a pesantren applies is also cosidered as the main factor of the

\footnotetext{
${ }^{7}$ Rahardjo, Intelektual Intelegensia dan Perilaku Politik Bangsa; Risalah Cendekiawan Muslim. (Bandung: Mizan, 2009), 191.

${ }^{8}$ Nashir, Mencari Tipologi Format Pendidikan Ideal Pondok Pesantren di Tengah Arus Perubahan. (Yogyakarta, Pustaka Pelajar, 2005), 23.
} 
success of education since it dissociates the santries from the life reality full of deviation, and designs an Islamic environment.

According to the researcher, however, it is the halaqah learning system applied in the pesantren that strongly influences the success of the character education so that the graduates of pesantren applying the halaqah system have certain characteristics compared those from other formal educations.

In the context of education, halaqah is considered to have developed as the alternative model in the Islamic education succeeding in forming Islamic personality among its members. It can be seen from its roles in building a moslem young generation with good spirits in understanding and performing Islamic teaching.

From the history of Islam, halaqah is actually one of the models of group missionary endeavors which was first made by the Prophet Mohammad secretly through routine meetings held in his comrade's home Arqam bin ABil Arqam (Mahmud, 2008: 129). It is in this place that the Prophet actively gave intensive guidance to his comrades who then become the first generation who were adherents of Islam in the Mecca period. This model was then preserved, and performed either secretly or openly and developed by the post-prophet generation through various meetings held by the Prophets' comrades, tabi' in, and so on.

The halaqah system is the oldest system in pesantren and certainly was the essence of teaching in pesantren in the past. All of them cannot be separated from the historical context in the establishment of an education institution of classical Islam which at first started in religious teachings in mosques, surau and langgar to study $\mathrm{Al}$ Qur'an, books on aqidah, fiqih, and Arabic. The halaqah teaching model certainly gave a great influence to the character of the santries in the pesantren, even halaqah is the special characteristic of the pesantren it self.

Pondok pesantren al-Islam in its learning system adopts the halaqah system as done by others, but what is unique in this pesantren al-Islam is that it has adopts this halaqah system is not merely to improve the santries' reading skill of kitab gundul (books on Islamic religion written in Arabic without any sign for long or short pronunciation) but also to build their rabbani character so that they have Islamic personality and are always to be sent to any regions to have some missionary endeavors of Islam and to struggle for Islam.

Based on the phenomena and descriptions above, the writer is interesting I studying halaqah in forming the santries' characters in Pesantren al-Islam Lamongan.

\section{B. Research Methods}

This research was a qualitative, an approach resulted descriptive data which were in written or oral data from people and behaviors that could be observed $^{9}$.

This research aimed to answer question about what and how an occurrence and reported the results as the way they were. Through this research, it was expected it could explore the concept of halaqah in forming the santries' characters in Pesantren al-Islam Lamongan.

In this research, the writer chose the research subject at Pesantren al-Islam because Pesantren al-Islam has

\footnotetext{
${ }^{9}$ Moleong, Metodologi Peneltian Kualitatif. (Bandung: Remaja Rosdakarya, 2003), 4.
} 
implemented halaqah program as a means of learning methods and the formation of character.

The research used two types of data; primary data and secondary data. The primary data were resulted from the principal and the director of Pondok Pesantren as the stakeholders. Meanwhile, the secondary data in this research were school documents such as geographical, profile, work programs of Pondok Pesantren etc.

To obtain clear, accurate and complete information, the researcher used several methods; observation, interview and documentation.

\section{Results}

\section{Specific Tradition of Halaqah in} Pesantren al-Islam

Halaqah in Pesantren al-Islam is a means of realizing the khiththah of this pesantren: creating a rabbani generation. There are seven educational objectives serving as the basis for realizing the halaqah in Pesantren al-Islam:

1) Possessing faith and sincerity as the good deed

2) Understanding the correct ways in praying

3) Having laudable characters

4) Owning good spirituality

5) Having wide scientific insights

6) Enjoying healthy and strong physical condition

7) Being ready to make missionary endeavors.

They seven objectives serving as the basis for all halaqah programs in Pesantren al-Islam are categorized into two halaqah models namely taklim and tarbiyah. Detailed explanations about the matters will be given below.

a. Possessing faith and sincerity as the basis for doing good deeds
Pesantren al-Islam gave a priority over the importance of implanting faith and sincerity in doing good deeds to the santries as the realization of the halaqah programs as stated in the khiththah of the pesantren: to cadre the santries possessing a pure tauhîd colloring all their lives, since faith is the motor of all human activities. A good behavior is the mirror of a good faith, whereas, a bad behavior is the mirror of a bad faith. Therefore, one of the halaqah programs implemented in the Pesantren is a belief (aqidah) halaqah.

In the belief halaqah, some books written by Muhammad bin Abdl Wahab namely al-ushûl al-tsalâtsah, alqawâ'id al-arba', Kasyfu syubhat, masâ'il al-jâhiliyah, and al-tauhîd were studied. The five books are expected to be able to flourish a firm faith among the santries and to give a deep knowledge of faith especially in rububiyah dan uluhiyah tauhîld, since the book al-ushûl al-tsalâtsah contains very basic and important lessons to realize personalities of a moslem believing in God in all their life sides. The nature of worshipping of a moslem is Allah Ta'ala, and the nature of a religion accepted by Allah is Islam, and the nture of a model for moslem is the Prophet saw.

Meanwhile the book al-qawâ'id al-arba' contains four basic norms in the faith principles:

1) It is determined that the Rububiyyah tauhîd requires the determination of the Uluhiyyah taunîd (worship)

2) The Musyrikin people fought against by the Prophet Muhammad saw, did not consider Allah as an ally in His Rububiyyah, but in His Uluhiyyah (worship)

3 The essence of shirk (syirik) in the Uluhiyyah is all the same, but what 
the Musyrikin people worship are different

4) It is determined that shirk the people have at present is more serious than that during the Prophet saw era.

The book kasyfu syubhat contains some objections to the reasons given by common people in making shirk to legitimate their shirk. The santries are expected not to be traped in the appearance of sleaze which seems as if it is a truth because it has been mixed with poisons in the form of confusing thoughts. Therefore, they may be able to distinguish between tauhîd and shirk clearly and to see shirk as a sleaze and tauhîld as a truth. This makes them not be fallen into a trap in the characteristic of reversing a nature namely believing a shirk as tauhîd.

The book masâ'il al-jâhiliyah discusses jahiliyah behaviors and characters fought against by the Prophet saw. This book contains 128 points dealing with jahiliyah cases. Understanding the badness, the santries are expected to be able to recognize and to avoid them.

The book al- tauhîd talks about the nature of tauhitd, the peculiarity of tauhid, the merits for those doing tauhîd, the threats for dose ignoring tauhîd, obligations in spreading tauhîd, the meaning of syahadat (the profession of faith) lâ ilâha illallah, and anything that may damage and deface tauhîid.

b. Understanding the correct ways in praying

Pesantren al-Islam in its various educationl programs educated the santries to become persons with good worshipping activities. In order to worship in the correct way as the Prophet saw modelled, this pesantren promoted the halaqah figh program with the aim of studying some books on mu'tabar fiqih, among others: matan alghâyah wa al-taqrîb, Umdatul ahkam, and Bulûghul marâm.

The three books are expected to be able to provide the santries with adequate knowledge on the right ways in praying based on shahih dalil. The book matan al-ghâyah wa al-taqrîb discusses an Islamic fiqih knowledge in a brief and an easy way special for the beginners. The book Umdatul ahkam contains fiqih hadits selectively chosen from the stories of Bukhari and Muslim that have clear keshahihan. Bulughul maram contains figh hadits of seven prominent Hadits experts namely Imam Bukhari, Muslim, Abu Daud, Tirmidzi, Nasai, Ibnu Majah, and Imam Malik so that it is expected that this book may be able to give wide insights of figh to the santries. Moreover, this book makes the santries to be used to encountering the dalils so that each ibadah they do is based on shahih dalils. According to the researcher, the teachings of halal and haram and worship are beneficial for the rabbani personalities of the moslems since athe best profile of a moslem is that he/she must be diligent in worship.

\section{c. Having laudable characters}

Pesantren al-Islam really paid attention to the guidance of the santries' characters. Halaqah tarbiyah is a medium for the formation of the santries' characters in this pesantren through halaqah al-Qur'an in which proper behaviors as santries and teachers of al Qur'an, besides memorizing some juzzes of al-Qur'an as prerequisite of the graduation, were taught. Moreover, Islamic characters in the book minhaj almuslim in general studies were also learned. Beside the halaqah method, a close relationship between the santries 
and the teachers also helps the santries to establish their personalities since the teachers may become the model of the santries. The halaqah tarbiyah in Pesantren al-Islam was projected to educate the santries' characters as the realization of the educators' responsibility to their santries.

\section{d. Owning good spirituality}

Pesantren al-Islam paid attention to the tazkiyah al-nafs matter to its santries. Therefore, one of the halaqah tarbiyah programs is a general study discussing the book Riyâdhush shâlihîn containing the tazkiyah al-nafs. Some activities are made aiming at the tazkiyah al-nafs realized in for examples the sunnah fasts " Monday-Thursday" and the together night praying and also the mau'idzah programs.

The tazkiyah al-nafs progam implemented in Pesantren al-Islam is aimed at educating the santries to posses some spiritual intelligence as stated by Ginanjar ${ }^{10}$ that any ability in giving the meaning of ibadah to each behavior and activity through tauhîhdi (integralistic) steps and thoughts with the "merely because of God" principle.

Ulwan $^{11}$ explains that spiritual education is to educate santries to be able to control their desires or emotions, and to adorn themselves with all forms of self magnificence either spiritually or moraly in an absolute way. The aim of this education is to form, complete and to balance the santries' personality so that they are able to do their duties well and meaningfully.

\footnotetext{
${ }^{10}$ Ary Ginanjar, Emotional Spiritual Quotient. (Jakarta: Arga, 2001), 51.

${ }^{11}$ Ulwan, Tarbiyatul Aulad fil Islam (pendidikan anak dalam Islam). Terj. Arif Rahman. (Solo: Insan Kamil, 2015), 239.
}

e. Having wide scientific insights

Islamic education not only include the faith and character education, but also the rational education. Ulwan ${ }^{12}$ states that the rational education is intended to form the santries' ways of thinking over anything beneficial, either syar' $i$ knowledge, culture, modern science, awareness, thought or civilization. Therefore, the santries have mature thoughts and adequate knowledge and cultures.

Pesantren al-Islam makes use of halaqah taklim to provide the santries with wide sciencetific insights, especially syar's knowledge. Moreover, this pesantren also has a fathul program requiring santries to stay in the pesantren library and to write papers and baths when the santries are in the KMI class. This educates them to be diligent with reading and studying various literatures provided by the pesantren in the library.

f. Enjoying healthy and strong physical condition

Physical condition was also paid attention in education through physical education intended to make santries grow well and to become mature with strong and healthy physical condition so that they may do all of their duties. Moreover, this physical education was also aimed at creating some awareness that they have to maintain their health by avoiding consuming any substances harmful to their bodies such as alcoholic drink, narcotics, drugs, and the like.

Ulwan $^{13}$ states that among the responsibilities the teachers should bear

\footnotetext{
${ }^{12}$ Ulwan, Tarbiyatul Aulad fil Islam (pendidikan anak dalam Islam). Terj. Arif Rahman. (Solo: Insan Kamil, 2015), 119.

${ }^{13}$ Ulwan, Tarbiyatul Aulad fil Islam (pendidikan anak dalam Islam). Terj. Arif Rahman. (Solo: Insan Kamil, 2015), 163.
} 
is to maintain the children's physical education with the aim of making their santries have strong and healthy physical condition and good spirits. Islam has outlined some methods in physical education so that the santries understand their own responsibilities and mandate God has given to them.

Pesantren al-Islam held various sports done in groups such as running together, football, swimming, selfdefense, and the like, including in the programs of halaqah tarbiyah. Consequently, these sports programs usually begins with tausiyah from the teachers so that the objective of the programs is to practice God's commandment saying "And prepare against them whatever you are able of power and of steeds of war (QS. ALAnfal: 60). The Prophet Muhammad saw also said: "Strong believers are betters and are more loved by Allah than the weak believers" (Muslim).

g. Being ready to make missionary endeavors.

Pesantren al-Islam through halaqah tarbiyah expects its santries as the cadres of revival mullahs with mental and scholarly readiness. So, in the halaqah "dakwah" and "amal islamy" they should study some books containing materials for doing their missionary endeavors and they also were also trained to do taklim quro activities intended to make them close to the taklim and missionary endeavors world.

Based on the descriptions above, it is concluded that halaqah is able to form the santries' characters, namely rabbani characters formed under 7 aspects: faith, morals, spirituality, scientific insights, physical condition, and readiness to do missionary endeavors.

\section{Halaqah as a Education System to Form Rabbani Character}

The results of the research on halaqah either the taklim or tarbiyah in Pesantren al-Islam support the conclusion that halaqah may adequately become an effective alternative method in the Islamic education system to form muslims with Islamic personalities. It can be seen from the results of serious efforts to practice and to struggle Islam.

The halaqah education system is the system that had been made use of by many generations and people, for examples, pious salafs, the Prophet Muhammad saw to his comrades, then the comrades to their tabi'in and so on regardless of ages in implanting Islamic characters. Halaqah is an education system uniting the science, practices, and cultures so that in this thalabul ilmi, some blessings are obtained.

Therefore it can be stated that a successful halaqah is the one oriented into producing high-quality cadres of Islam in terms of their science and personality. If the quality is not reached, halaqah merely becomes routine activities without giving any significant effects on the participants. As a result, there are four elements to pay attention to realize a successful halaqah:

1) Comprehensive Learning Scheme

An ideal halaqah is the one with a comprehensive learning scheme covering various aspects of rabbani muslim character building. In Pesantren al-Islam, the halaqah education covered faith, pray, characters, spirituality, scientific insights, physical condition, and readiness to do missionary endeavors aspects . 
Ulwan $^{14}$ explains that to build the santries' characters to possess excellent Islamic personalities, the education not only include the faith education, but also cover moral, physical, intellectual, mental and also social educations.

The faith education serves to bind the santries with faith basis, Islamic principles and syariat basis. Moral education is a group of basis of moral education and superiority of attitude and behaviors that should be possessed by a santry and that becomes his habits from his tamyiz to mukallaf (puberty) phases. This gradually continues to the adult phase so that he is ready to wade his life ocean.

Physical education is aimed at making the santries able to grow adult with strong and healthy physical condition and also with full of spirit. The rational education, however, is intended to form the santries' ways of thinking over anything beneficial, such as syar'i knowledge, culture, modern science, awareness, thought or civilization. So that the antries will be mature in terms of their thoughts, and their sciencetific and cultural insights.

Mental education is to educate santries to be brave and frank, self-help, autonomous, to like to help others, to control their emotions, and to color themselves with all forms of honors mentally and morally in an absolute way. Meanwhile, social education is intended to teach santries to stick to the main social ethic and noble mental bases coming from the Islamic belief and sincere faith feelings. The objective of social education is to make santries present themselves in the community as a generation that is able to make some

\footnotetext{
${ }^{14}$ Ulwan, Tarbiyatul Aulad fil Islam (pendidikan
} anak dalam Islam). Terj. Arif Rahman. (Solo: Insan Kamil, 2015), 105-110. social interactions well, ethically, maturily and wisely.

Character education in halaqah should pay attention to some aspects of education, and to create some habits among the santries with the hope that the values of the goodness may become their characters rooting in their mind, since human beings are not the moving objects, but consist of spirits and bodies. The characters seen are the fruits of the faith and spirituality existing in their mind and souls. Human beings are created not for their own lives, but for serving as social creatures living and socializing with others.

\section{2) Murabbi with good characters}

Murabbi plays the main role in halaqah since he functions as the changer, colorer, adviser, builder, director, and model for the halaqah participants. There are some basic characters that support someone to do their duties as educators. The "perfection" character on human beings is only possessed by the Prophets, but human beings may also try with a great effort to attain good and laudable characters. This effort should always be made by those becoming the focus of model for their santries, educators and advisers. Some basic characters possessed by the murabbis that influence the halaqah participants and that result in stronger responses to the murabbis are as follows:

\section{a) Sincerity}

An educator should have sincere intentions because of Allah in doing his each duty, either in the form of giving instruction, prohibition, advices, attention, or punishment. The sweet fruit from this sincerity is seriousness in performing any educational scheme so that he may always be able to follow 
and control the education of the halaqah participants continuously besides getting rewards and ridha from Allah and a noble place in the heaven.

According to Ulwan ${ }^{15}$, sincere in educating is one of the principles of faith and demands of Islam, since Allah will not accept any good deeds if the deeds are not done without any sincerity. It is stated by the Prophet Muhammad saw that "Allah SWT will not accept any good deeds except being made in sincerity and expecting His ridha. (HR. Abu Daud dan Nasa'i).

b) Piety

It is a character a murrabi should posses; he will not do anything Allah forbides and will not leave Allah instructs, he keeps himself from any tortures made by Allah through good deeds, he feels he is affraid of Him, either secretly or vertly.

According to Ulwan ${ }^{16}$ (2015: 645) an educator should possess this piety character so that Allah will endow him with prestige, namely keeping him from any torments from Allah through his feeling of being always controlled by Allah, and encouraging him to do Allah's rules either when he is alone or when he is together with others. Moreover, he will also always try to look for something halal and to avoid anything haram.

Murabbi should be the one with good piety because he is the model for the halaqah participants. The main method adopted in the halaqah education is to educate santries through modelling. Modelling in education is the

${ }^{15}$ Ulwan, Tarbiyatul Aulad fil Islam (pendidikan anak dalam Islam). Terj. Arif Rahman. (Solo: Insan Kamil, 2015), 644.

${ }^{16}$ Ulwan, Tarbiyatul Aulad fil Islam (pendidikan anak dalam Islam). Terj. Arif Rahman. (Solo: Insan Kamil, 2015), 645. most effective and successful method in preparing santries in terms of their characters, either their mental or social characters. This is because an educator is the model or ideal or a good example for santries. Santries will consciously or unconsciously immitate behaviors and characters an educator shows. Even, all his words and acts will be recorded and melted in the minds of his student and are part of their perception.

\section{c) Devoutness ('âlim)}

Murabbi should be someone with good knowledge on educational pinciples stated in Islam syariat, halal and haram, piety principles and global rules in Islam and syariat principles because all of these may make him place anything in the proper place wisely, educate children in accordance with principles of education and the demand, and do on the ishlah way based on strong principles from the teachings of al-Qur'an, the guidance of the Prophet Muhammad saw, and from models from pious old generations namely the comrades, and their goodness after that.

Whereas, if an educator knows little this matter, especially in the main principles of education, this results in santries' disordered psychological conditions, deviating characters, and weak social abilities. The santries will be useless human beings and will not be considered in this life, because they have nothing to give. A murrabi with no correct knowledge will not be able to guide his santries to become someones with good devoutness (knowledge).

Ulwan $^{17}$ explains that there are may verses and hadits motivating ones to study. It is an instruction to educators

\footnotetext{
${ }^{17}$ Ulwan, Tarbiyatul Aulad fil Islam (pendidikan anak dalam Islam). Terj. Arif Rahman. (Solo: Insan Kamil, 2015), 649.
} 
to provide themselves with useful knowledge and science, and to have good teaching methods in order to make their santries to become someones with good devoutness so that the generation of Islam will be able to be bright with the light of science.

d) Politeness and Forgiving

Another important character that may help in a murabbi's success in doing his duty is his politeness and forgiving. It is through this attitude, his santries will behave properly and avoid any improper behaviors. This condition will encaurage the murabbi to have good spirits in educating and guiding his santries, and to be patient in doing his tasks.

Therefore, the instruction to be polite is repeated several times in some verses of the QSs, such as QS. Ali Imran: 134, QS. Al-A'raf: 199, al-Syura: 43, QS. Fushilat: 34 intended to give some awareness of politeness to the educators since politeness is one of the nobilities of soul and laudable charactes. In the history of Muslim, Rasulullah saw explained that isnt' suavity (politeness) in something except coloring, and if it omitted from the thing, it must become bad.

Ulwan $^{18}$ explains that what educators should do is to show politeness and suavity in educating santries, if they want to develop the ummah, to give hidayah to the next generation, to straigthen the santries' education. It does not mean, however, that educators should always show some suavity in educating the santries, because "suavity" here means to control any emotion when they are angry with santries that show improper behaviors.

${ }^{18}$ Ulwan, Tarbiyatul Aulad fil Islam (pendidikan anak dalam Islam). Terj. Arif Rahman. (Solo: Insan Kamil, 2015), 651.
Therefore, if educators see that a condition requires him to admonish or even to hit santries, they should do it as long as it is intended to make santries' behaviors become better.

3) Dynamic Halaqah Process

Dynamic halaqah is the one which is always in process and changeable movements, so that this raises some enthusiasm and omits any boredom. But it is not easy, since the halaqah system have no time limitation, proceeds routinely and never ends to follow except the participants want to quit from the halaqah or a halaqah relating to a certain institution.

What to do to avoid some boredom in the halaqah situation is to create a dynamic journey of the halaqah, by varying Islamic creative ways such us adopting some learning methods like sorogan, bandongan, mudzakara, modeling, habituation, advices (mau'idzah), lecturing, tikrar (repetition), reward and punishment.

Giving attention to the proceeding of dynamic and encouraging halaqah system is very urgent, either by the murrabis or the halaqah participants, since any neglect to the dynamism will give impacts on the slow attainment of the objective. Murabbi and the halaqah participants are rarely aware of this condition, since they feel that anything works well in the halaqah. Some murabbis employe an attendance indicator as the way to make an appraisal of an halaqah. When all participants are present, he thinks that the halaqah runs well. This kind of the appraisal is inadequate, others indicators should be included namely inadequate, others indicators should be included namely dynamization and productivity of the halaqah. 
According to Lubis ${ }^{19}$,
dynamization will measure the murabbis' and participants' satisfaction with their activities in the halaqah. This satisfaction is subjective since it is related to emotion (feeling). Although it is subjective, it does not mean that satisfaction should be ignored in appraising the success of the halaqah. The satisfaction paradigm to mesure the success in the human resource management is commonly adopted in the field of organization and management. Halaqah as a system of human resource management needs to pay attention to this matter.

The followings are some benefits obtained from dynamic activities in the halaqah:

a) Routine attendance

b) High spirit

c) Great responsibility in doing tasks of the halaqah

d) Acceleration in the objective attainment

e) Increase in the creativeness

f) Reduction of conflicts

g) Feeling of enjoyable ukhuwah.

Whereas the halaqah which is not dynamic will result in some boredom. The boredom may be caused among others by:

a) The learning system. The boredom is caused by the static learning system, for example, the learning activity is merely held in a room where santries sit, whereas the activity may be done in the classroom, at the outdoor, in the mosque, employing a majelis taklim method, and the like.

b) The presentation method. The boredom is caused by monotonous

${ }^{19}$ Lubis, Menggairahkan Perjalanan Halaqah: Kiat agar Halaqah Lebih Dahsyat Full Manfaat. (Yogyakarta: Pro-U Media, 2010), 38. presentations of the materials, for example, the method is merely the lecturing, without employing any other methods such as discussions, seminars, case studies, simulations, book reviews, and the like.

c) Learning media/tools. It is caused by monotonous learning facilities, such us photo copies, whereas there are other learning media line white boards, OHPs (over head projector), LCDs, visual aid sheets, simulation/demonstration tools, and so on.

d) Monotonous materials. This boredom is caused by monotonous materials. Although the materials are different, but the descriptions, illustrations, theorems, or the examples are monotonous and recurring.

e) It is caused by monotonous arrangements and types of program agenda in each halaqah meeting.

f) Meeting time. It is caused by fixed times, for instances, the meeting is always held on Friday night.

g) Meeting place. It is resulted from the fact that the place of each meating is never changed, for example in the murrabi's house.

h) Participant composition. This boredom is caused by unchanged composition of the participants. The composition of the participants in the halaqah has never changed for years.

4) Halaqah Productivity

Productivity is the quantity of results (objectives) one reaches in joining in the halaqah. It can be seen from two aspects: quantity and quality. The more and the higher quality of the objectives to be reached in a halaqah, the more productive of the halaqah will be. On the contrary, the less and the 
lower the objectives are reached, the less productive of the halaqah will be $\mathrm{be}^{20}$.

The objectives (aims) should be formulized in each halaqah so that it has certain direction and targets to attain. The objectives (aims) in a halaqah among others are as follows:

a) The attainment of muwashafat of the levels

Productivity of halaqah is appraised from the number of the participants coming into the next level.

This level rise is measured the participants attain the muwashafat (characteristics) determined for each level. Halaqah is a learning system uniting knowledge and tarbiyah. The quality of the participants is considered from the the knowledge mastered, the personal characters and the quality of practices of the worship performed. As the medium of making cadres, halaqah should posses some measurements of characters that are expected to be realized by the participants. It is the characters which are realized called muwashafat. The task of murabbis is to guide the participants to attain the determined muwashafat, so that they may rise to the next level.

b) The attainment of the formation of the cadres of murrabis

As the media of creating cadres, productivities of a halaqah is measured from the participants' success in becoming murabbis. Since a rabbani muslim is not only pious for himself, but also his environments and is trying to make people around him pious like himself. Halaqah tries to mold cadres as the Prophet Muhammad saw did namely, making his comrades become qualified

${ }^{20}$ Lubis, Menggairahkan Perjalanan Halaqah: Kiat agar Halaqah Lebih Dahsyat Full Manfaat. (Yogyakarta: Pro-U Media, 2010), 66. murabbis ready to do missionary endeavors to whole regions in the earth.

Allah swt also instructs us to become rabbani persons with a characteristics of "always teach the Scriptue and stay to learn it" (QS. Ali Imran: 79). A muslim may not always become a student or mad'u, instead of teacher or dai. But the halaqah participants are not merely to become ordinary dais, but also the dais who are able to manage halaqah (become murabbis), since it is merely murabbis who have great opportunities in changing people into the ones with Islamic personalities. Any missionary endeavors will have few opportunities to change persons into the ones with Islamic personalities, if the endeavors just depend on forums of 'ammah endeavors such as tabligh, lecturing, reading books, seminars and the like.

\section{Discussion}

From the character building point of view, halaqah is an ideal medium for building rabbani characters and is one of the implementations of the Islamic education principle, "long-life learning" since the nature of halaqah is that it does not consider the age, time and space limitations. This finding is in line with that by Muskinul Fuad stating that halaqah is a model of group guidance to develop muslims' personalities. Halaqah has some characteristics: it is ukhuwahnuanced, the world and hereafterdimensioned, comprehensive, authoritybased, and it also has functions of understanding, prevention, problem solving, and development. Consequently, halaqah may be used as one of the alternative models of guidance groups with multi-purpose, multi-function, multi-content, multiprocess, multi-method, and multi-media. 
Character building is not merely done by teaching good characters as stated by the theory of character education proposed by Thomas Lickona namely knowing the good, desiring the good, and doing the good. It is in line with Munjin, Ghufran, Walid, and Afandi's research result. This present research result complement Thomas Lickona's theory in terms of the concept of character education, and previous research results. According to the researcher, character education and improvement are not merely done by paying attention to the character, but to the three main elements to be successful, namely strong piety, correctness and spirits in worshiping so that one is close to the Creator, and good character with fellow human beings as experiences of the characteristics of al-Rahman in ordering the nature and in taking care of His servants since human beings are the caliph of Allah in the earth, so that it is a must to make the divine values as the paradigm in behaviors. If the three elements are paid attention it will bear santries with good relationship with the Creator, themselves, and the fellow creatures. Allah will not accept one's characters if he is not willing to believe and to worship Him, as stated in the QS. Surah al-Furqan: 23. So, Imam alGhazali when explaining the concept of tazkiyat al-nafs, begins discussing characters, especially tauhîhd and 'ibadah. According to Ulwan, in explaining the concept if child education in Islam, states that moral education is not enough. But piety, rational, social, mental and physical educations should be implanted.

Based on the descriptions above, rabbani character education should be oriented into foive religion pillars: piety, courtesy, character, worship, and muamalat. If the five pillars are paid attention in education, the education will bear human beings with strong piety, good character and courtecy, and with good ability in interaction with the community and in involving themselves in he life in line with their skills.

This research finding also develops theories proposed by alGhazali and Ulwan in child education, especially in technical matters in implementing the education or group guidance either in formal of informal institution.

\section{E. Conclusion}

Based on the research described, it can be concluded that: (1) the halaqah practiced in the pesantren al-Islam was based on the ideas presented by the kyais and the management as formulized in the khiththah of the pesantren namely to have a rabbani generation with faith and sincerity, good morals, high spirituality, wide knowledge insights, healthy and strong physical condition, and readiness to make some propaganda about Islam. (2) the implementation of halaqah in Pesantren al-Islam may be classified into two categories. (a) halaqah taklim, intended to give some insights to the santries on the right aqidah and the correct worship. The employed techniques of the halaqah implementation were bandongan, sorogan or the combination of the two. (b) halaqah tarbiyah, intended to build santries to become muslims with noble morals and with some awareness and spirits of teaching and of struggling Islam. The technique of the halaqah implementation is to give materials of tazkiyat al-nafs accompanied with 'amaliah ibadah sunnah, and teaching and harakah materials and also guidance 
in reciting the Holy Qur'an and in guiding the characters.

\section{References}

Al-A'dhami, M.M. (1413H). Dirasaat fil Hadits al-Nabawi. Beirut: alMaktab al-Islami.

Afandi, R. (2011). Integrasi Pendidikan Karakter dalam Pembelajaran IPS di Sekolah Dasar. Paedagogia, Jurnal Penelitian Pendidikan Vol. 1, No. 1, h. 85-98.

Ainiyah, N. (2013). Pembentukan Karakter melalui Pendidikan Agama Islam. Jurnal al-Ulum Vol. 13, No. 1, h. 25-38.

Arikunto, S. (1991). Prosedur Peneltian Suatu Pendekatan Praktek. Yogyakarta: PT. Rineka Cipta.

Creswell, J.W. (2013). Reseach Design: Pendekatan Kualitatif, Kuantitatif, dan Mixed. Terj. Achmad Fawaid. Yogyakarta: Pustaka Pelajar.

(2013). Penelitian Kualitatif \& Desain Riset. Yogyakarta: Pustaka Pelajar.

Departemen Agama RI (2001). "Pola Pembelajaran di Pesantren". Dirjen Bimbingan Islam, Proyek Peningkatan Pondok Pesantren.

Dhofier, Z. (2011). Tradisi Pesantren; Study tentang Pandangan Hidup Kyai. Jakarta: LP3ES.

Fuad, M. (2013). Halaqah Sebagai Model Bimbingan Kelompok untuk Mengembangkan Kepribadian Muslim (Studi Etnografis pada Komunitas Jama'ah Tarbiyah di Kota Purwokerto). Disertasi. Bandung: Universitas Pendidikan Indonesia.
Al-Ghazali (1980). Ihya' ulum al-din. Beirut: Dar al-Fikr.

Ghufron, A. (2010). Integrasi Nilai-Nilai Karakter Bangsa Pada Kegiatan Pembelajaran. Jurnal Cakrawala Pendidikan Edisi Khusu Dies Natalis UNY, No. 2, h. 13-24.

Ginanjar, A. (2001). Emotional Spiritual Quotient. Jakarta: Arga.

Hawwa, S. (1984). al-Mustakhlash fi tazkiyat al-Nufus. Mesir: Dar al-Salam.

Ibnu Maskawaih, tt, Tahdzib al-Akhlaq. Kairo: Darul Kutub al-Ilmiah.

Ishomuddin (1997). Sosiologi Perspektif Islam. Malang: UMM Press.

Al-Jauziyah, I.Q. (2001). Ighatsatul Lahfan. Beirut: Darul kitab alArabi.

Lickona, T. (2012). Character Matters: Persoalan Karakter, terj. Juma Wadu Wamaungu, editor Uyu Wahyuddin dan Suryani. Jakarta: Bumi Aksara.

(2012). Educating for Character: Mendidik untuk Membentuk Karakter, terj. Juma Wadu Wamaungu, editor Uyu Wahyuddin dan Suryani. Jakarta: Bumi Aksara.

Lubis, S.H. (2010). Menggairahkan Perjalanan Halaqah: Kiat agar Halaqah Lebih Dahsyat Full Manfaat. Yogyakarta: Pro-U Media.

Mahmud, A.A.H. (2004). Akhlak Mulia. Jakarta: Gema Insani. . (2008). Perangkat-Perangkat Tarbiyah Ikhwanul Muslimin. Surakarta: Era Intermedia.

Moleong, L.J. (2003). Metodologi Peneltian Kualitatif. Bandung: Remaja Rosdakarya.

Mukhtar, M. (2001). Madrasah; Sejarah dan Perkembangannnya. 
Jakarta: PT. Logos Wacana Ilmu.

Mulkan, (2013), Paradigma Intelektual Muslim. Yogyakarta: Sipress.

Munjin (2008). Internalisasi Nilai-Nilai Budi Pekerti Pada Anak. Jurnal Komunika Vol. 2, No. 2, h. 219-232.

Al-Nadawi, A.H.A. (1969). Nahwa alTarbiyah al-Islamiyah alHurrah fi al-Hukumat wa alBilad al-Islamiyah. Beirut: Darul Irsyad.

Nashir, M.R. (2005). Mencari Tipologi Format Pendidikan Ideal Pondok Pesantren di Tengah Arus Perubahan. Yogyakarta: Pustaka Pelajar.

Nata, A. (2013). Kapita Selekta Pendidikan Islam. Depok: PT. Rajawali Pres.

Rahardjo, D. (1983). Dunia Pesantren dalam Peta Pembaharuan. Jakarta: LP3ES.

(2009). Intelektual Intelegensia dan Perilaku Politik Bangsa;
Risalah Cendekiawan Muslim. Bandung: Mizan.

Steenbrink, K.A. (1986). Pesantren, Madrasah, Sekolah; Pendidikan Islam dalam Kurun Modern. Jakarta: LP3ES.

Tafsir, A. (2010). Filsafat Pendidikan Islami. Bandung: PT. Rosda.

(2012). Ilmu Pendidikan Islami. Bandung: PT. Rosda.

Tobroni (2010). The Spiritual Leadership. Malang: UMM Press.

Ulwan, A.N. (2015). tarbiyatul aulad fil Islam (pendidikan anak dalam Islam). Solo: Insan Kamil.

Walid, M. (2011). Model Pendidikan Karakter di Perguruan Tinggi Agama Islam; Studi tentang Pendidikan Karakter berbasis Ulul Albab di Universitas Islam Negeri Maulana Malik Ibrahim Malang. Jurnal alQudwah Vol. 1, No. 5, h. 115156. 